\title{
Estimating rainfall infiltration for groundwater recharge using infiltration index method: A case study in Rajshahi District, Bangladesh
}

\author{
Tofatun Jannat ${ }^{1}$, Anupam Chowdhury ${ }^{1, *}$, Mohammed Ziaur Rahaman ${ }^{2}$, Kazi Moinul Islam ${ }^{2}$ \\ ${ }^{1}$ Department of Civil Engineering, Rajshahi University of Engineering \& Technology, Rajshahi, Bangladesh \\ ${ }^{2}$ Department of Civil Engineering, Southern University Bangladesh, Chittagong, Bangladesh
}

\section{Email address:}

tofatunjannat@gmail.com (T. Jannat), anupam.19ce@gmail.com (A. Chowdhury), ziaruetce1@yahoo.com (M. Z. Rahaman), moince70@gmail.com (K. M. Islam),

\section{To cite this article:}

Tofatun Jannat, Anupam Chowdhury, Mohammed Ziaur Rahaman, Kazi Moinul Islam. Estimating Rainfall Infiltration for Groundwater Recharge Using Infiltration Index Method: A Case Study in Rajshahi District, Bangladesh. American Journal of Civil Engineering.

Vol. 2, No. 3, 2014, pp. 91-95. doi: 10.11648/j.ajce.20140203.15

\begin{abstract}
Infiltration rate in soil is a measure at which the soil is able to absorb rainfall. It replenishes the soil moisture deficiency and the excess moves downward by the force of gravity called deep seepage or percolation and builds up the groundwater table. The study was conducted in three large Upazilas under Rajshahi district from 2002 to 2013 to estimate the rainfall infiltration for groundwater recharge which are the pre-condition to meet the large demand of irrigation supplies that are the key to economic growth. Rainfall data was collected from Upazila Agriculture Office DAE, Rajshahi. The data were analyzed to show the rainfall variations, runoff, infiltration rate and percentage of infiltration from total rainfall for different years. In this paper, W-index method was used for better and quick assessment of rainfall infiltration in study areas. The result illustrate that the average annual rainfall Infiltration rate were found $80.61,79.12$ and $72.20 \mathrm{~cm} /$ year for Godagari, Paba and Puthia Upazila respectively and the average percentage of annual infiltration from total rainfall were found $58.3 \%$, $58.76 \%$ and $58.80 \%$ for three study areas respectively.
\end{abstract}

Keywords: Rainfall, Runoff, Infiltration, Groundwater, W-index

\section{Introduction}

Bangladesh is the land of rivers, a number of rivers crossed over it but the surface water is not enough to meet irrigation water demand in dry season. Agriculture in the Bangladesh depends on irrigation during the dry season of eight months starting from November and ending in June. During dry season, groundwater is the major source of water for domestic and the irrigation purposes. The Barind area of Rajshahi zone is mainly depends on groundwater for irrigation.

Groundwater is basically a dynamic resource that may be expressed as the quantity of water measured by the difference between optimum and minimum water table within the aquifer, which is principally recharged from monsoon rainwater for the rest of the year. Exploitation or over withdrawal of groundwater resources imposes stress on groundwater regime distorting the aquifer recharge-withdrawal equilibrium and as a result, a continuous decline in water table may occur cause much adverse surface and subsurface environmental effect [1]. Groundwater recharge is influenced not only by climate variability but also human intervention including, unsustainable withdrawal and groundwater abstraction. Groundwater-fed irrigation is conducted to cultivate high-yielding rice during the dry season in South Asia, where India and Bangladesh represent the world second and fourth biggest rice-producing nations respectably [2].

In Bangladesh, total annual (2004-2005) irrigation water use was estimated to be $246 \mathrm{Km}^{3}$ of which $18 \mathrm{~km}^{3}$ comes from groundwater via a range of pumping technologies [3]. Recent studies in India and Bangladesh reported that a groundwater level (0.1-0.5 $\mathrm{m} / \mathrm{year})$ was declining indicating reduction in aquifer storage for unsustainable groundwater abstraction for both irrigation and urban water supplies [4]. In India, Punjab and Haryana are experiencing very rapid decline in water tables. This can threaten future food security in the country [5]. 
The maximum rate at which the soil in any given condition, capable of absorbing water is called its infiltration capacity. The amount of rainfall infiltrating into the soil is important for plant growth, irrigation purpose, water storage capacity and many other natural or manmade process. The infiltrated water after meeting the soil moisture insufficiency deeply percolates and builds up the ground water table. The increase in groundwater storage can be achieved by increasing rainfall infiltration rate and reducing surface runoff, evapotranspiration etc. The infiltration depends upon the intensity and duration of rainfall, weather (temperature), soil characteristics, vegetal cover, land use, initial soil moisture content, entrapped air and depth of the groundwater table. The vegetal cover provides protection against rain drop impact and helps to increase infiltration [6]. In the study areas, surface water sources are negligible, groundwater is the main source of irrigation system. So the main objective of this paper is to know how much rainfall is infiltrated into the soil to build up groundwater table.

\section{Materials and Methods}

\subsection{Selection of Study Areas}

The study areas are situated in the northern part of Bangladesh, named Rajshahi district. Gadagari, Paba and Puthia are the three largest upazila of Rajshahi district and it lies under the Barind tract and the Padma river passing through these sites was shown in "Fig. 1". The Rajshahi Barind tract is located in between 24 degree 23 minute to 25 degree 15 minute north latitude and 88 degree 2 minute to 88 degree 57 minute east longitude. A typical dry climate with comparatively high temperature prevails in these areas. The three selected areas are prominent for agricultural areas and most of the people are farmers. For proper irrigation management system the prime needs to know about the yearly infiltration rate which finally builds up the ground water storage.

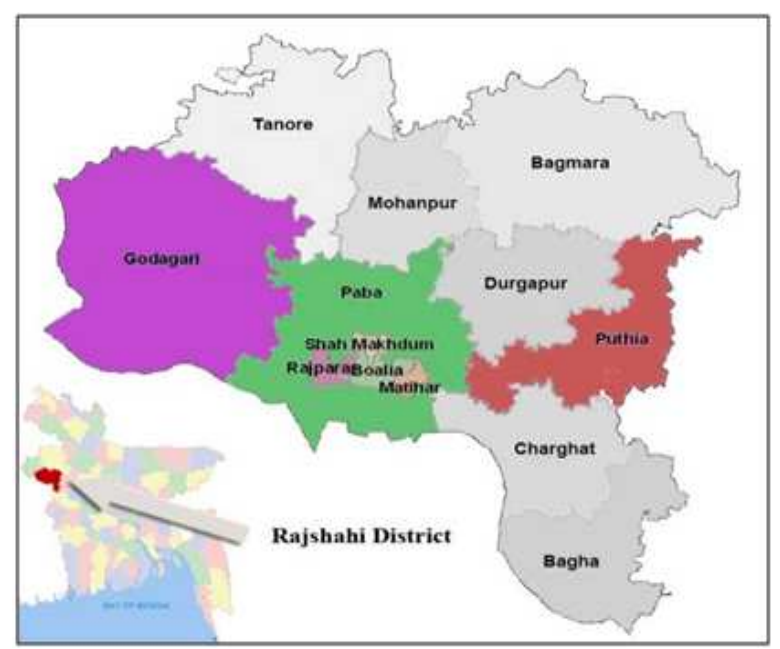

Figure 1. Location of Study Areas at Rajshahi district (source: bpedia.org).

\subsection{Data Collection}

Rainfall data required for the selected study area has been collected from Upazila Agriculture Office of Godagari, Paba and Puthia; Deputy Director's Office of Department of Agriculture Extension (DAE) of Rajshahi zone for twelve years from 2002 to 2013 .

\subsection{Runoff}

During the rainfall, a portion of rainfall infiltrates into the ground and some portion may evaporate. The rest flows as a thin sheet of water over the land surface which is termed as surface runoff. The runoff is more uniform compared to precipitation, while the precipitation is sporadic and irregular in nature. This contrast between precipitation and runoff is due to the storage effects of the surface layers of the earth. Runoff can be calculated using the following equation "(1)",

$$
\mathrm{R}=\mathrm{P} \times \mathrm{K}_{\mathrm{b}}
$$

Where,

$$
\begin{aligned}
& \mathrm{R}=\text { Runoff }(\mathrm{cm}) \\
& \mathrm{P}=\text { Total Rainfall }(\mathrm{cm}) \\
& \mathrm{Kb}=\text { Runoff Coefficient. }
\end{aligned}
$$

\subsection{Infiltration}

Infiltration is the process by which water enters into the soil at the ground surface. The infiltrated water first meets the soil moisture deficiency, if any, and further the excess water moves vertical and inclined direction to reach the groundwater table. Infiltration rate can be determined using W- index method from following equation "(2)". The Windex is the average infiltration rate where rainfall intensity exceeds the infiltration capacity rate.

$$
\mathrm{W} \text {-index }=\frac{\mathrm{P}-\mathrm{R}}{\mathrm{t}}
$$

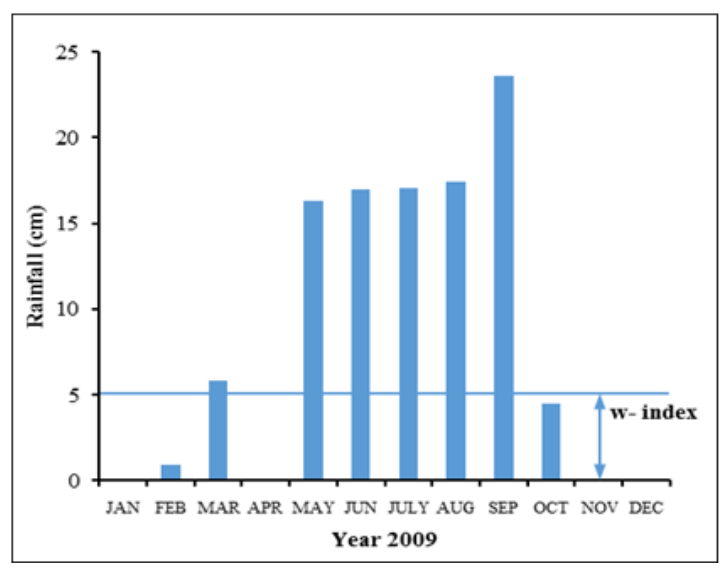

Figure 2. Estimation of infiltration loss by $W$-index.

Where,

$\mathrm{P}=$ Total Rainfall $(\mathrm{cm})$

$\mathrm{R}=$ Surface Runoff $(\mathrm{cm})$

$\mathrm{t}=$ Duration of Storm (hr.) 
From "Fig. 2", if w- index is greater than rainfall intensity, then infiltration is equal to rainfall. And if the W-index is less than rainfall intensity then infiltration is equal to $\mathrm{w}$-index [6].

\section{Result and Discussion}

\subsection{Rainfall Variation}

The monthly rainfall variations of three upzilas of the

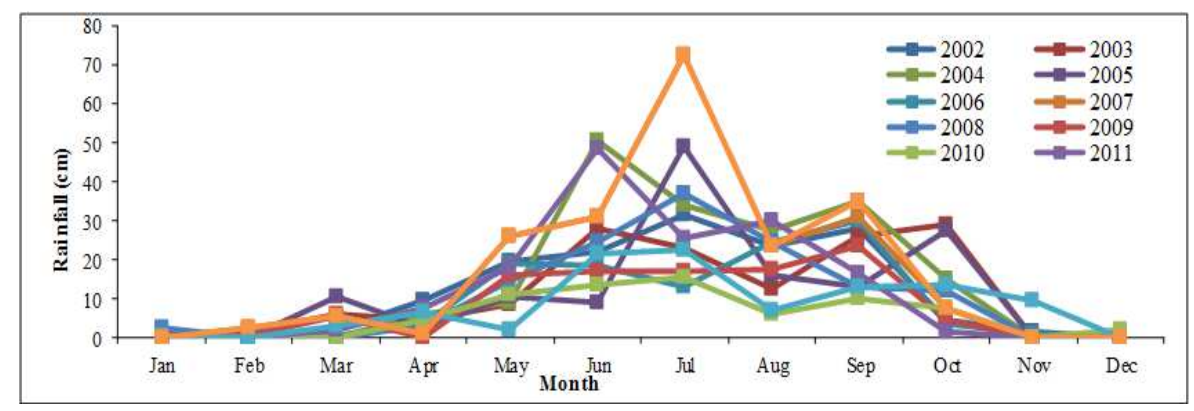

Figure 3. Monthly rainfall variation at Godagari.

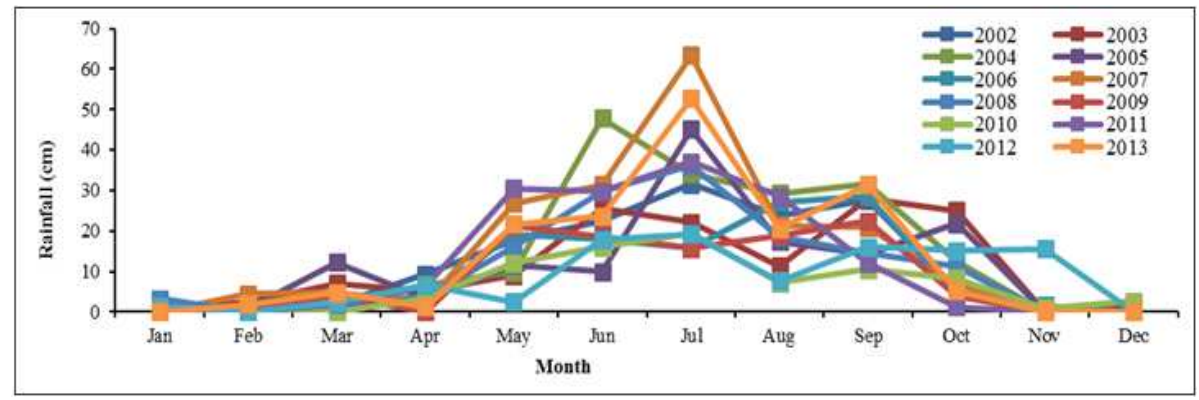

Figure 4. Monthly rainfall variation at Paba.

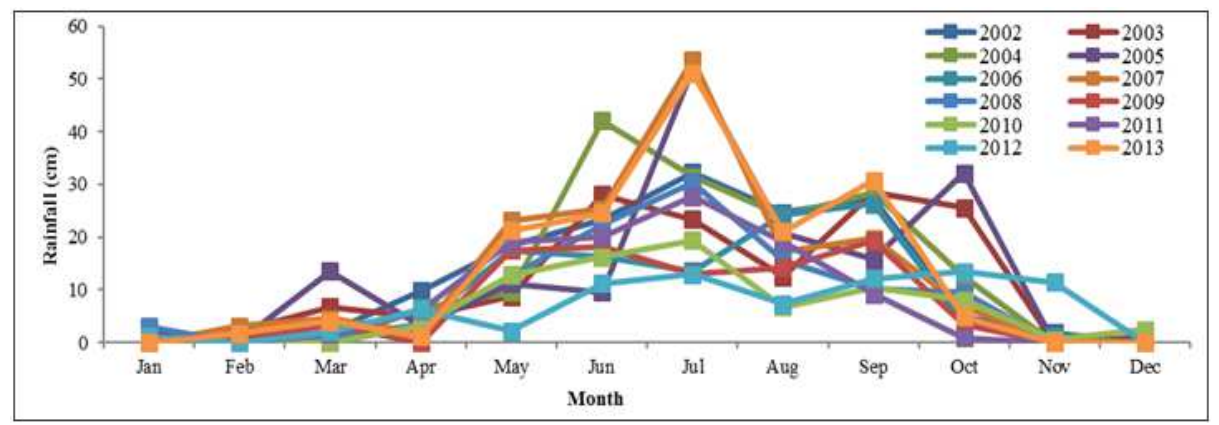

Figure 5. Monthly rainfall variation at Puthia.

The yearly rainfall variations of three upzilas of the study areas during 2002-2013 are shown in "Fig. 6". The maximum annual rainfall recorded was $205.9 \mathrm{~cm}$ in 2013 . Since then, rainfall was gradually decreasing for consecutive three years, but in 2007, the annual rainfall increased by $70.30 \mathrm{~cm}$ from $131.5 \mathrm{~cm}$ recorded in the previous year. The results show that Godagari Upazila received the highest rainfall $205.9 \mathrm{~cm}$ in 2007 and simultaneously received the lowest rainfall $71.50 \mathrm{~cm}$ in 2010 during the study period of the area. Among the three upazilas Puthia received the low intensity rainfall around all the years relative to Godagari and Paba. The average rainfall received in Puthia Upazila was $124.3 \mathrm{~cm}$ during 2007-2011. study areas during 2002-2013 are shown in "Figs. 3-5". The maximum rainfall was found throughout June to September during the rainy season of the area. The minimum rainfall was found between February and April and very little or no rainfall occurred during November to January in the study area. The study results also illustrate that the maximum rainfall was recorded at Godagari in July, 2013, Paba in July, 2007, Puthia in July, 2007. 


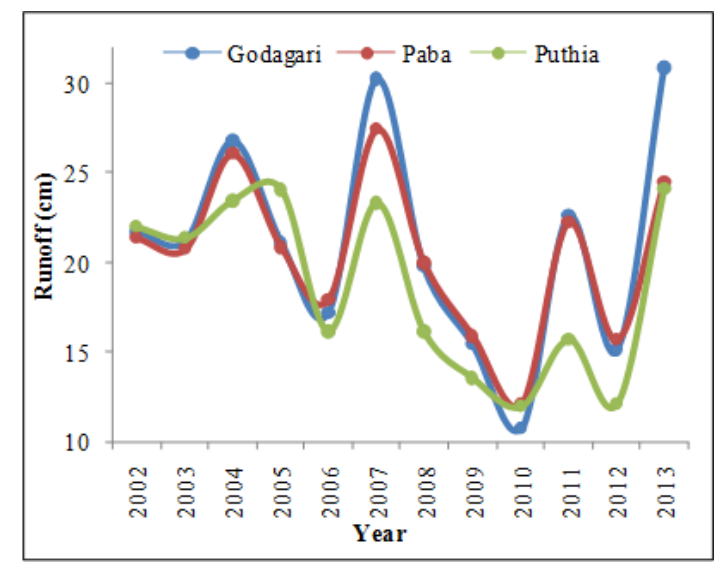

Figure 7. Annual variation of runoff at Godagari, Paba and Puthia

\subsection{Estimated Runoff}

"Fig. 7" shows that the maximum estimated runoff was found in 2013 during the study period as the rainfall received. Since then, runoff was gradually decreasing for consecutive three years, but it was increased in all Upzilas of the district in 2007 as expected due to higher rainfall received in this year. From "Table 1" the study results show that the highest runoff estimated was $30.89 \mathrm{~cm}$ in 2013 in Godagari Upzila and received the lowest runoff was $10.73 \mathrm{~cm}$ in 2010 during the study period.

Table 1. Estimated runoff of three Upazilas in Rajshahi district from 2002 to 2013

\begin{tabular}{llll}
\hline Year & Godagari & Paba & Puthia \\
\hline 2002 & 21.68 & 21.39 & 22.04 \\
2003 & 21.18 & 20.76 & 21.38 \\
2004 & 26.79 & 26.07 & 23.44 \\
2005 & 21.08 & 20.81 & 24.06 \\
2006 & 17.18 & 17.88 & 16.12 \\
2007 & 30.27 & 27.44 & 23.31 \\
2008 & 19.73 & 19.97 & 16.10 \\
2009 & 15.39 & 15.87 & 13.49 \\
2010 & 10.73 & 12.11 & 11.97 \\
2011 & 22.63 & 22.28 & 15.71 \\
2012 & 15.10 & 15.68 & 12.05 \\
2013 & 30.89 & 24.47 & 24.09 \\
\hline
\end{tabular}

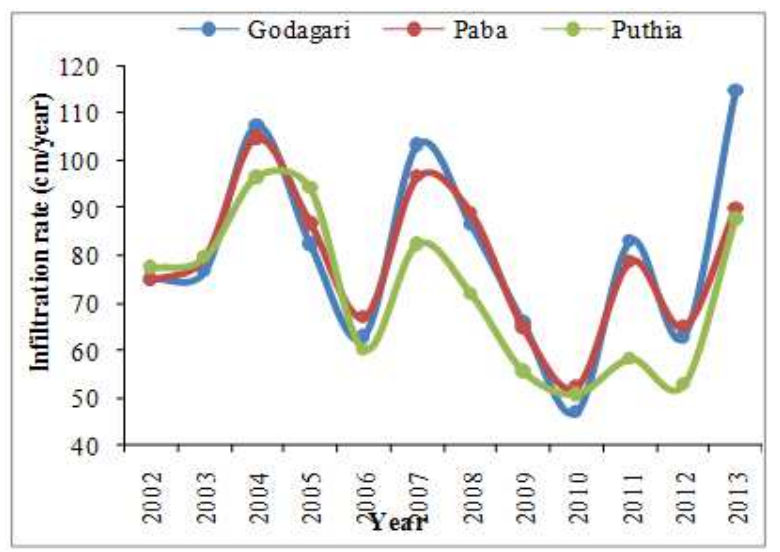

Figure 8. Annual variation of infiltration rate at Godagari, Paba and Puthia.
Table 2. Estimated infiltration of three upazilas in Rajshahi district from 2002 to 2013

\begin{tabular}{llll}
\hline Year & Godagari & Paba & Puthia \\
\hline 2002 & 75.03 & 74.90 & 77.36 \\
2003 & 76.55 & 79.67 & 79.46 \\
2004 & 107.51 & 104.77 & 96.52 \\
2005 & 82.37 & 86.75 & 96.52 \\
2006 & 62.73 & 66.99 & 60.24 \\
2007 & 103.37 & 96.63 & 82.35 \\
2008 & 86.49 & 88.81 & 71.80 \\
2009 & 65.70 & 64.81 & 55.49 \\
2010 & 46.86 & 52.31 & 50.58 \\
2011 & 83.18 & 78.76 & 58.10 \\
2012 & 62.78 & 65.01 & 52.65 \\
2013 & 114.73 & 90.02 & 87.64 \\
\hline
\end{tabular}

\subsection{Estimated Infiltration}

Infiltration rate was calculated using $\mathrm{W}$ - index method which states that if $\mathrm{W}$ - index is greater than rainfall intensity, then infiltration is equal to rainfall. And if, W-index is less than rainfall intensity then infiltration equal to w-index.

From "Fig. 8" the infiltration data of Rajshahi district illustrate that the highest rainfall infiltration was estimated in 2013 during the study period as the maximum rainfall received, since then, infiltration was gradually decreasing for consecutive three years, but the increased amounts of infiltration was estimated in 2004 compared to the previous year in all Upzilas as expected due to higher rainfall received in this year. From "Table 2" the study results show that the estimated highest infiltration was $114.73 \mathrm{~cm}$ in 2013 at Godagari Upzila and simultaneously received the lowest infiltration was $46.86 \mathrm{~cm}$ in 2010 .

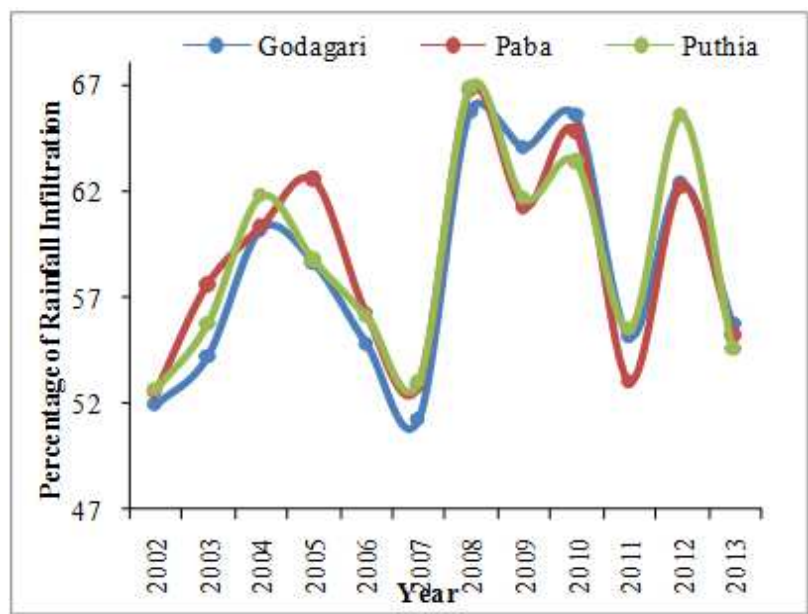

Figure 9. Annual variation of percentage of rainfall infiltration at Godagari, Paba and Puthia. 
Table 3. Estimated percentage of rainfall infiltration of three upazilas in Rajshahi district from 2002 to 2013

\begin{tabular}{llll}
\hline Year & Godagari & Paba & Puthia \\
\hline 2002 & 51.92 & 52.52 & 52.66 \\
2003 & 54.22 & 57.57 & 55.76 \\
2004 & 60.19 & 60.28 & 61.76 \\
2005 & 58.63 & 62.54 & 58.75 \\
2006 & 54.79 & 56.20 & 56.06 \\
2007 & 51.22 & 52.83 & 52.99 \\
2008 & 65.77 & 66.72 & 66.92 \\
2009 & 64.04 & 61.25 & 61.69 \\
2010 & 65.54 & 64.82 & 63.39 \\
2011 & 55.14 & 53.03 & 55.50 \\
2012 & 62.37 & 62.21 & 65.57 \\
2013 & 55.72 & 55.19 & 54.57 \\
\hline
\end{tabular}

From "Table 3" the study results show that the percentage of infiltration from total rainfall during the period of the study. The results show that the maximum percentage of rainfall infiltration was obtained in 2008 during the period of study. Highest percentage of rainfall infiltration was found $66.92 \%$ in Puthia upazila in 2008 and lowest percentage of rainfall infiltration was found $51.22 \%$ in Godagari upazila in 2007 during the period of the study was shown in "Fig. 9". The average percentage of rainfall infiltration was found $58.3 \%, 58.76 \%$ and $58.80 \%$ for three study areas respectively.

\section{Conclusion}

The study results illustrate that the maximum rainfall occurred during June-August and little or no rainfall was recorded during December-February. Thus the maximum runoff and infiltration were estimated during June-August. The variations of average annual rainfall, runoff and infiltration rate were found almost same trend for three selected study areas.

Using W-index method, infiltration rate for any area can be determined quickly and easily using only rainfall data. The average annual infiltration rate for study areas were found varies between 72 to $81 \mathrm{~cm} /$ year. The annual average percentage of rainfall infiltration of the selected study areas were found quite different. On the average almost $58 \%$ of total rainfall are infiltrated into ground in the study areas annually and which finally increase the groundwater recharge. However, this estimated value will be helpful for proper estimating annual groundwater storage from rainfall, fluctuation of water table and crop irrigation demand in the study areas as well as will be successfully applied for the similar tropical region in Bangladesh.

\section{References}

[1] S. K. Garg, Irrigation Engineering and Hydraulic Structures (Khanna publishers 2-B, Nath Market, Nai Sarak, Delhi-110006, 1976).

[2] C. A. Scott and B. Sharma, Energy supply and the expansion of groundwater irrigation in the Indus-Ganges Basin. Intl $\mathrm{J}$ River Basin Mange, Vol. 7, 2009, 1-6.

[3] M. R. Hasan, M. G. Mostafa and I. Matin, Effect of Groundwater Level Fluctuation in Chapai Nawabgonj District, International Journal of Engineering Research \& Technology (IJERT), 2 (4), April 2013, 2800-2807.

[4] S. Siebert, J. Burke, J. M. Faures, K. Frenken, J. Hoogeveen, P. Doll, F. T. Portmann, Groundwater use for irrigation: a global inventory. Hydrol Earth Syst Sci Discuss, Vol. 7, 2010, 3977-4021.

[5] Tribune News Service. Power Woes Return with Paddy Season. Tribune India. Retrieved from http://www.tribuneindia.com/2006/20060613/punjab1.htm\# 12. (2006, June 13)

[6] H. M. Raghunath, Hydrology 1st ed., H.S. Poplai for New Age International (P) Limited, 4835/24, Ansari Road, New Delhi-110002,1997.

[7] Banglapedia: Godagari, Paba, Puthia upazila, National Encyclopedia of Bangladesh, Website http://bpedia.org (last visit: 10-2-2014). 